\title{
Gastrin Significantly Modifies the Migratory Abilities of Experimental Glioma Cells
}

\author{
Florence Lefranc, Isabelle Camby, Nathalie Belot, Erik Bruyneel, \\ Carole Chaboteaux, Jacques Brotchi, Marcus Mareel, Isabelle Salmon, and \\ Robert Kiss
}

\author{
Departments of Neurosurgery (FL, JB) and Pathology (IS), Erasmus University Hospital, and Laboratory of \\ Histopathology (IC, NB, CC, RK), Faculty of Medicine, Université Libre de Bruxelles, Brussels; and Laboratory of \\ Experimental Cancerology (EB, MM), University Hospital, Ghent, Belgium
}

\begin{abstract}
SUMMARY: Malignant astrocytic tumors are characterized by the pronounced and diffuse migration of tumor astrocytes into the brain parenchyma. The present study shows that gastrin is a brain neuropeptide that is able to significantly modulate astrocytic tumor migration at both invasion and motility levels. In the matter of invasion, gastrin severely reduces the in vitro invasive abilities of 66 rat glioma, 9L rat gliosarcoma, and U373 human glioma cells in a collagen matrix. In vitro, gastrin also markedly modifies the motility features in both C6 and U373 cells, at least partly through a decrease in the expression of the RhoA small GTPase, and so brings about some dramatic modifications to the organization in the actin cytoskeleton. The in vitro preincubation of C6 tumor cells with gastrin significantly increases the life spans of rats stereotactically implanted with these cells as compared with the survival periods of rats implanted with gastrin-untreated C6 cells. As suggested by our in vitro experiments, these effects, observed in vivo cannot relate to only the gastrin-induced decrease in tumor astrocyte migratory abilities. Indeed, gastrin also induces immunomodulatory effects, because we observed a marked gastrin-induced recruitment of lymphocytes into C6 gliomas and $9 \mathrm{~L}$ gliosarcomas. These data all suggest that gastrin can act as an endogenous modulator of glioma progression. (Lab Invest 2002, 82:1241-1252)
\end{abstract}

$B$ rain tumors constitute approximately $10 \%$ of all solid tumors in adults and between $20 \%$ and $30 \%$ in children (Burger and Scheithauer, 1994; Kleihues and Cavenee, 2000). Approximately one-third are/diffuse astrocytic tumors (astrogliomas) associated with dismal prognoses because of their pronounced ability to diffusely invade the brain parenchyma. Their level of malignancy increases from astrocytomas (World Health Organization/WHO Grade II) to anaplastic astrocytomas (WHO Grade III) and glioblastomas (WHO Grade IV) (Kleihues and Cavenee, 2000). The invasive abilities of individual tumor astrocytes depend mainly on their migratory potential (Chintala and Rao, 1996; Giese et al, 1994), and part of this potential depends on the organization of the actin cytoskeleton (Cramer and Mitchison, 1993; Lauffenburger and Horwitz, 1996).

\section{DOI: 10.1097/01.LAB.0000029151.37006.9E}

Received May 31, 2002.

This work has been carried out on the basis of grants awarded by the Fonds de la Recherche Scientifique Médicale (FRSM, Belgium), the Fondation Yvonne Boël (Belgium), the Fondation Rose et Jean Hoguet (Belgium), the Association Sportive Contre le Cancer (Belgium) and the Fondation Cancer Solidarite (Switzerland). FL is the holder of a grant from the Fondation Erasme (Belgium) and RK is a Director of Research with the Fonds National de la Recherche Scientifique (FNRS, Belgium).

Address reprint requests to: Dr. Robert Kiss, Laboratory of Histopathology, Faculty of Medicine, Free University of Brussels, 808 route de Lennik, 1070 Brussels,Belgium.E-mail: rkiss@ulb.ac.be
Whereas gastrin is known to significantly modulate both the proliferation levels of many tumor types (Rehfeld/and van Solinge, 1994) and the migration levels of various cell types of the immune system (de la Fuente et al, 1997, 1998), we were the first to show that gastrin is able to modulate both proliferation (Camby et al, 1996) and migration (De Hauwer et al, 1998) in human tumor astrocytes. These data could relate to the fact that cholecystokinin (CCK) and CCK-related peptides (gastrin) constitute the most abundant peptide system in the brain (Rehfeld and van Solinge, 1994), with gastrin-induced effects mediated through the $\mathrm{CCK}_{\mathrm{B}}$ receptor. This receptor is the predominant $\mathrm{CCK} /$ gastrin receptor of the central nervous system (CNS), whereas the $\mathrm{CCK}_{\mathrm{A}}$ receptor, which is a thousand times more specific to sulfated CCK-8 than to gastrin, is predominant outside of the CNS (Rehfeld and van Solinge, 1994). Normal astrocytes possess significant amounts of $\mathrm{CCK}_{\mathrm{B}}$ receptors (Hosli and Hosli, 1994) and might be a major primary target for CCK/gastrin peptides in the CNS (Muller et al, 1997).

Although during the last 3 years we have accumulated a large set of data indicating that gastrin targets several genes directly involved in the proliferation and migration features of tumor astrocytes (see "Discussion"), neither we nor anyone else has investigated the potential role played by gastrin in in vivo glioma progression. In our study, we therefore made use of the C6 rat and the U373 human astroglioma models (and to a lesser extent the 9L rat gliosarcoma) to 
investigate gastrin-induced effects in vitro with respect to invasion and motility. For our in vivo experiments, we made use of stereotactic implantations of $\mathrm{C} 6$ and 9L tumor cells into rat brains. The development of the $\mathrm{C} 6$ gliomas and 9L gliosarcomas in the brain was monitored by means of nuclear magnetic resonance (NMR) imaging, and once a rat began to lose weight, a surgical procedure was applied to remove the bulk of the $\mathrm{C} 6$ and $9 \mathrm{~L}$ tumor. Subcutaneously implanted micropumps were then used to deliver gastrin into the $\mathrm{C} 6$ and $9 \mathrm{~L}$ tumor resection cavities. C6 cells were also preincubated in vitro with various concentrations of gastrin before their stereotactic implantation into the rats' brains to study the direct effects of gastrin on in vivo C6 glioma progression. The potential gastrin-induced immunomodulatory counter-effects on C6 gliomas and 9L gliosarcomas stereotactically implanted into the rats' brains were also investigated, because gastrin has a chemotactic influence on a large set of cells of the immune system (de la Fuente et al, 1997, 1998). It should be emphasized that the C6 model suffers from some limitations because it is allogenic and so induces significant host-mediated immunogenic responses (Parsa et al, 2000). We therefore added to our in vivo experiments the $9 \mathrm{~L}$ gliosarcoma model as an internal methodologic control because this model is syngeneic and therefore weakly immunogenic (Parsa et al, 2000). The presence of mRNAs of cholecystokinin $\left(\mathrm{CCK}_{\mathrm{A}}\right)$ and gastrin $\left(\mathrm{CCK}_{\mathrm{B}}\right)$ receptors was assayed on the U373, C6, and 9L models by means of RT-PCR techniques. The presence of $\mathrm{CCK}_{\mathrm{C}}$ in human tumors, a third CCK/gastrin receptor, has already been described (Baldwin, 1994). We therefore also assayed the presence of mRNAs for $\mathrm{CCK}_{\mathrm{C}}$ receptors in the U373 human glioma model. Gastrin production in C6, 9L, and U373 cells was evidenced at both RNA and protein levels by means of the quantitative RT-PCR and ELISA assay respectively.

\section{Results}

\section{Identification of $\mathrm{CCK}_{A}, \mathrm{CCK}_{B}$, and $\mathrm{CCK}_{C}$ Receptors and Gastrin RNAs}

Although U373 human glioma cells exhibit RNAs of $\mathrm{CCK}_{\mathrm{C}}$ receptors (Fig. 1B), we failed to evidence RNAs of either $\mathrm{CCK}_{\mathrm{B}}$ (Fig. 1A) or $\mathrm{CCK}_{\mathrm{A}}$ (data not shown) receptors. Although $\mathrm{C} 6$ tumor cells exhibit RNAs of $\mathrm{CCK}_{\mathrm{B}}$ (Fig. 1D), but not of $\mathrm{CCK}_{\mathrm{A}}$ receptors (Fig. 1C), the reverse was observed with respect to the $9 \mathrm{~L}$ tumor cells (Fig. 1, C and D).
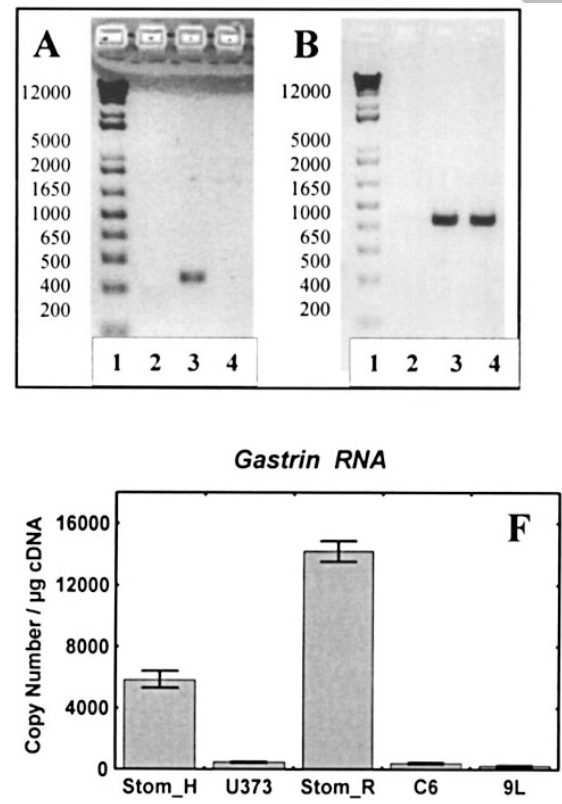
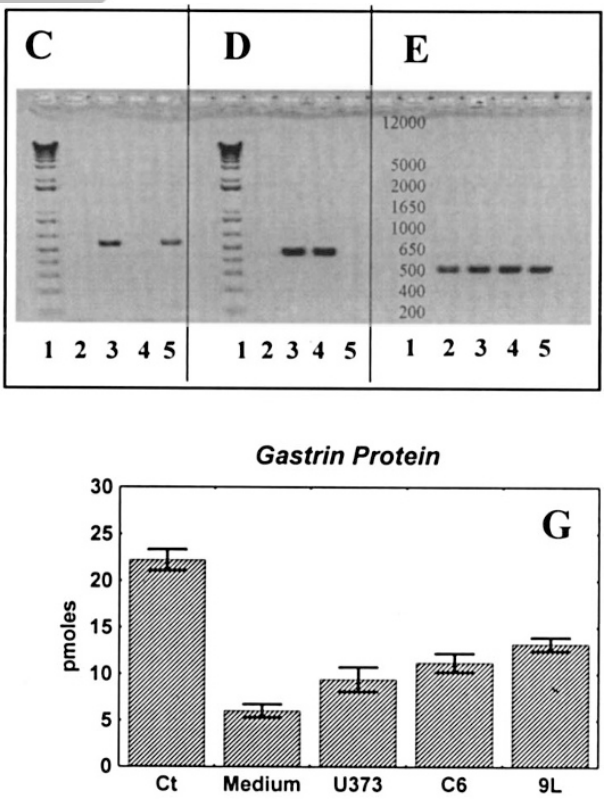

Figure 1.

A, Analysis of the expression of cholecystokinin (CCK) $)_{B}$ receptor RNA in U373 human gliomas (Lane 4) and human Jurkat cells chosen as positive control (Lane 3). Lane 2 corresponds to negative control $\left(\mathrm{H}_{2} \mathrm{O}\right)$, and Lane 1 to the molecular weight markers. $\mathrm{B}$, Analysis of the expression of CCK $\mathrm{C}_{\mathrm{C}}$ receptor RNA in U373 human

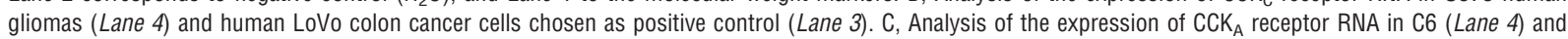
9L (Lane 5) rat tumor cells. Lane 3 corresponds to a positive control, normal pancreatic rat tissue. Lane 2 corresponds to negative control $\left(\mathrm{H}_{2} \mathrm{O}\right)$, and $\mathrm{Lane} 1$ to the molecular weight markers. D, Analysis of the expression of CCK $\mathrm{B}_{\mathrm{B}}$ receptor RNA in C6 (Lane 4) and 9L (Lane 5) rat tumor cells. Lane 3 corresponds to a positive control, normal rat brain tissue. Lane 2 corresponds to negative control $\left(\mathrm{H}_{2} \mathrm{O}\right)$ and Lane 1 to the molecular weight markers. $\mathrm{E}$, Analysis of the expression of $\beta$-actin RNA in normal pancreatic rat tissue (Lane 2), 9L rat tumor cells (Lane 3), normal rat brain tissue (Lane 4), and C6 rat tumor cells (Lane 5). Lane 1 corresponds to negative control. The same characterization of $\beta$-actin RNA expression was also performed for the U373 tumor cells and their corresponding normal positive controls, ie, Jurkat and LoVo cells (not shown). F, Quantitative RT-PCR analysis of gastrin RNA in U373, C6, and $9 L$ tumor cells. Samples of human (Stom-H) and rat (Stom_R) stomach tissue were used as positive controls. Four independent experiments were carried out. The data are presented as mean \pm SEM values. G, Determination of gastrin protein amounts in U373, C6, and $9 \mathrm{~L}$ tumor cells by means of an ELISA assay. Ct represents a positive control condition in which $10^{-10} \mathrm{M}$ gastrin was added to a serum-free medium and assayed 24 hours later. Amounts of gastrin were also assayed in culture media supplemented with $10 \%$ fetal calf serum (medium), and in the culture media of C6, 9L, and U373 tumor cells 24 hours after their plating (5,000 tumor cells per milliliter of medium) into the culture media. Gastrin was assayed in the culture media free of tumor cells. 
We did not investigated the RNAs for the $\mathrm{CCK}_{\mathrm{C}}$ receptor in rat tumor cells because, to date, no $\mathrm{CCK}_{\mathrm{C}}$ receptor has been cloned in a rat. C6, 9L, and U373 cells produce weak but nevertheless significant amounts of gastrin. We evidenced this feature at both RNA (Fig. 1F) and protein (Fig. 1G) levels.

\section{In Vitro Gastrin-Induced Modifications to C6, 9L, and U373 Cell Migration (Invasion and Motility) Features}

We characterized the gastrin-induced effects on C6, 9L, and U373 cell invasion features by quantifying the percentage of $\mathrm{C6}, 9 \mathrm{~L}$, and $\mathrm{U} 373$ cells able to invade a collagen matrix. The data show that a 24-hour gastrin pulse induced a marked dose-dependent decrease in the invasiveness of the three experimental models (Fig. 2, A-C). Although the invasion by tumor astrocytes or gliosarcoma cells of type I collagen gels may have some relevance to their in vivo growth, it cannot be assumed that in vitro collagen invasion by tumor astrocytes and/or gliosarcoma cells is relevant in the case of brain invasion by glioma or gliosarcoma cells in which type I collagen is absent. We are setting up new tests involving laminins, fibronectins, and vitronectins in place of type I collagen.

Motility refers to a cell's capacity for locomotion. We used computer-assisted phase-contrast microscopy to quantify the gastrin-induced effects on C6 (Fig. 2D) and U373 (Fig. 2E) cell motility levels. Although gastrin induced a dose-dependent decrease in the U 373 cell motility level (Fig. 2E), it slightly increased the C6 cell motility level when added to the culture media at $10 \mathrm{~nm}$ (Fig. 2D). This effect on C6 cells was no longer statistically significant at $0.1 \mathrm{~nm}$ and $1,000 \mathrm{~nm}$ (Fig. 2D). Gastrin had no statistically significant influence on the motility levels of the $9 \mathrm{~L}$ cells (not shown).

L-365,260, a specific CCK ${ }_{B}$ receptor antagonist, significantly decreased the level of $\mathrm{C} 6$ motility when added to the culture media at 10 or $1,000 \mathrm{~nm}$ for at least 24 hours (Fig. 2D). This feature relates to the fact that $\mathrm{C} 6$ cells secrete gastrin, as we observed at both gastrin mRNA (by means of RT-PCR) and protein (by means of Western blotting analyses) levels (Fig. 1, F and G). Gastrin may therefore play an autocrine role in tumor astrocyte migration.

A marked decrease in 66 cell motility level was observed after 24 hours of videomicroscopy observation when the L-365,260 compound was added to the culture media at the same time as gastrin (both at 10 nм) (Fig. 2D). All of these features therefore suggest that the gastrin-induced increase in $\mathrm{C} 6$ cell motility occurs via the $\mathrm{CCK}_{\mathrm{B}}$ receptor. Indeed, when the $\mathrm{CCK}_{\mathrm{B}}$ receptor activity was blocked by means of the L-365,260 compound, gastrin induced a decrease in C6 cell motility, a phenomenon that may have taken place via the $\mathrm{CCK}_{\mathrm{C}}$ receptor as strongly suggested by the data obtained for the U373 model (Fig. 2E).

When gastrin was added 1 to 3 hours before its antagonist, the activity of the $\mathrm{CCK}_{\mathrm{B}}$ receptor was not blocked when $10 \mathrm{~nm}$ of gastrin was added to the culture media of the C6 cells. Consequently, gastrin was no longer able to significantly inhibit $\mathrm{C} 6$ cell motility through the $\mathrm{CCK}_{\mathrm{C}}$ receptors (Fig. 2D).

\section{Gastrin-Induced Modifications to the C6 Cell Cytoskeleton and the RhoA Protein Level}

One of the most important biologic features in cell motility is the question of actin polymerization/depolymerization dynamics. Although fibrillary actin can be demonstrated in cells by means of a phallotoxin derivative (phallacidin) conjugated with a green fluorochrome (Fig. 3, A and B), globular actin can be shown by means of DNAsel conjugated with a red fluorochrome (Fig. 3, A and B). Specific fibrillary/ globular actin ratios are related to maximum cell motility features (Lauffenburger and Horwitz, 1996). Culturing C6 cells for 24 hours with $10^{-8} \mathrm{M}$ gastrin markedly reduced the amount of fibrillary actin (Fig. $3 \mathrm{~B})$ as compared with what occurred when these cells were cultured in the absence of gastrin (Fig. 3A). The quantitative data obtained by means of computerassisted fluorescence microscopy show that gastrin markedly reduced the amount of fibrillary actin (in favor of globular actin) in a dose-dependent manner (Fig. 3C). These data should be seen in the light of those reported for the gastrin-induced modifications to C6 (Fig. 2D) and U373 (Fig. 2E) cell motility features.

Quantitative Western blotting indicated that gastrin significantly decreased the RhoA expression (a potent modulator of actin polymerization/depolymerization dynamics) (Fig. 3D). These data suggest that the gastrin-induced decrease in the amount of fibrillary actin observed in vitro (Fig. $3 \mathrm{C}$ ) might relate to the gastrin-iñdúced decrease in RhoA expression evidenced here.

\section{Gastrin-Induced Modifications to the Survival Periods of C6 Glioma-Grafted Rats}

To investigate whether gastrin is able to significantly modify the survival of rats intracranially grafted with the $\mathrm{C} 6$ model, we preincubated in vitro $\mathrm{C} 6$ cells with various concentrations of gastrin before stereotactically grafting these gastrin-treated cells into the rat brains. The fact of preincubating $\mathrm{C} 6$ cells in vitro with gastrin and then grafting them in vivo into rat brains enabled us to investigate whether gastrin-induced modifications to migration features (as detailed in Fig. 2), and consequently to the organization of the actin cytoskeleton (as detailed in Fig. 3), could influence the survival of rats stereotactically implanted with these gastrin-treated tumor astrocytes. The data in Figure $4 \mathrm{~A}$ clearly indicate that the 24-hour in vitro gastrin pretreatment of the $\mathrm{C} 6$ cells before their in vivo brain implantation significantly increased the rats' survival at the $10^{-8} \mathrm{M}$ and $10^{-10} \mathrm{M}$ doses, but not at the $10^{-6}$ $\mathrm{M}$ or the $10^{-12} \mathrm{M}$ doses. These data thus suggest that the $\mathrm{C} 6$ cells pretreated in vitro with gastrin partially lost their biologic aggressiveness when subsequently grafted in vivo into the rats' brains. As checked by means of the 3-(4,5-dimethylthiazol-2-yl)-2,5 diphenyl 

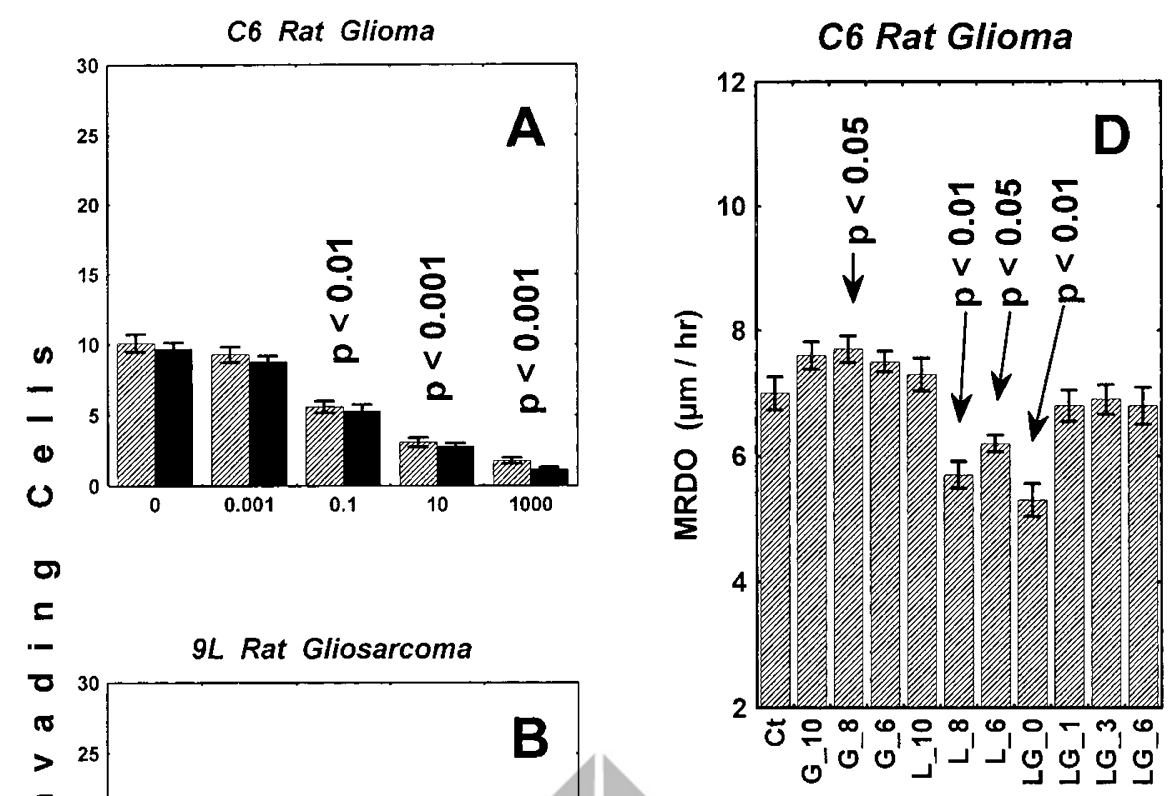

Experimental Conditions

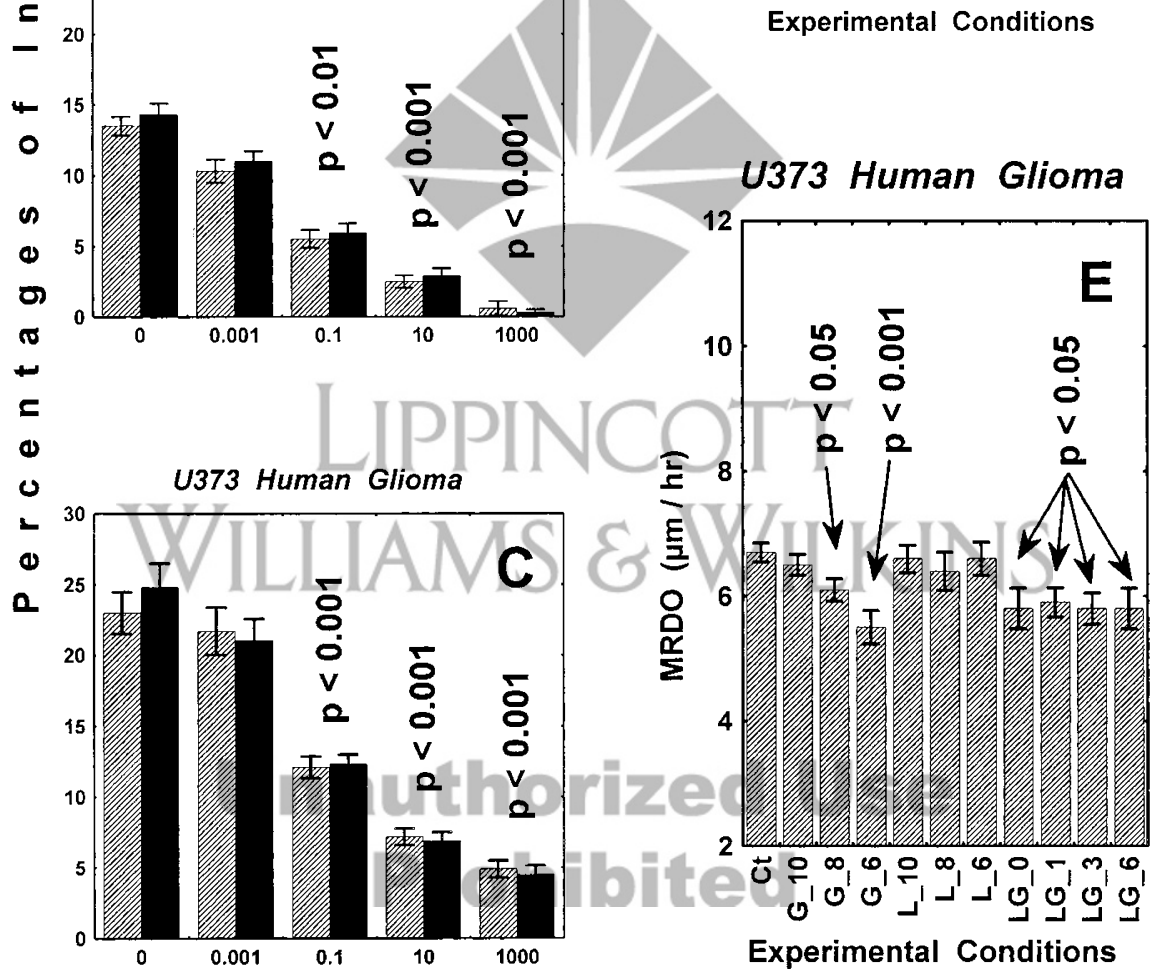

Figure 2.

A to $\mathrm{C}$, Characterization of the influence of gastrin on the invasive potential of the C6 rat glioma $(A)$, the $9 \mathrm{~L}$ rat gliosarcoma (B), and the U373 human glioma (C) models. The assay consisted of a $90 \%$ collagen I / 10\% collagen III matrix on which the cells were plated, and the numbers (expressed as percentages) of cells succeeding in invading this matrix were recorded. Two independent sets of experiments (black and shaded bars) were performed. The tumor cells were cultured for 24 hours with four different doses of gastrin before being plated on the collagen matrix. The thick bars represent the mean values and the lines above the bars represent the standard errors. Statistical analyses were performed by means of the Dunn procedure. $D$ and $E$, Characterization of the influence of gastrin ( $G$ ) and L-365,260 ( $\mathrm{L}$, a specific $\mathrm{CCK}_{\mathrm{B}}$ receptor antagonist) on the motility behavior (determined by the maximum relative distance from the point of origin [MRD0] variable) of the C6 (D) and U373 (E) tumor cells after 24 hours of quantitative videomicroscopy. The cells' motility behavior was evaluated for those left untreated (control

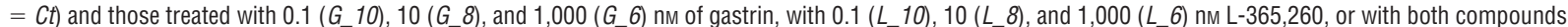
( $L G$ conditions). In this last set of experimental conditions, gastrin was always used at a $10 \mathrm{~nm}$ concentration and the $L-365,260$ compound was added at a 10 nm concentration, either at the same time as the gastrin ( $\left.L G \_0\right)$, or 1,3 , or 6 hours after the addition of gastrin ( $L G \_1, L G \_3$, $L G \_6$, respectively). Triplicate analyses were performed, with a minimum of 844 and a maximum of 1,008 cells analyzed in each experimental condition. The data are presented as means \pm their standard errors. Statistical analyses were performed by means of the Dunn procedure.

tetrazolium bromide (MTT) colorimetric assay, the levels of C6 tumor cell viability were similar $(p>0.05)$ in each control and gastrin-treated batch of C6 tumor cells grafted into the rats' brains (not shown). These gastrin-induced effects, illustrated in Figure 4A, were highly reproducible; similar data were obtained in a 

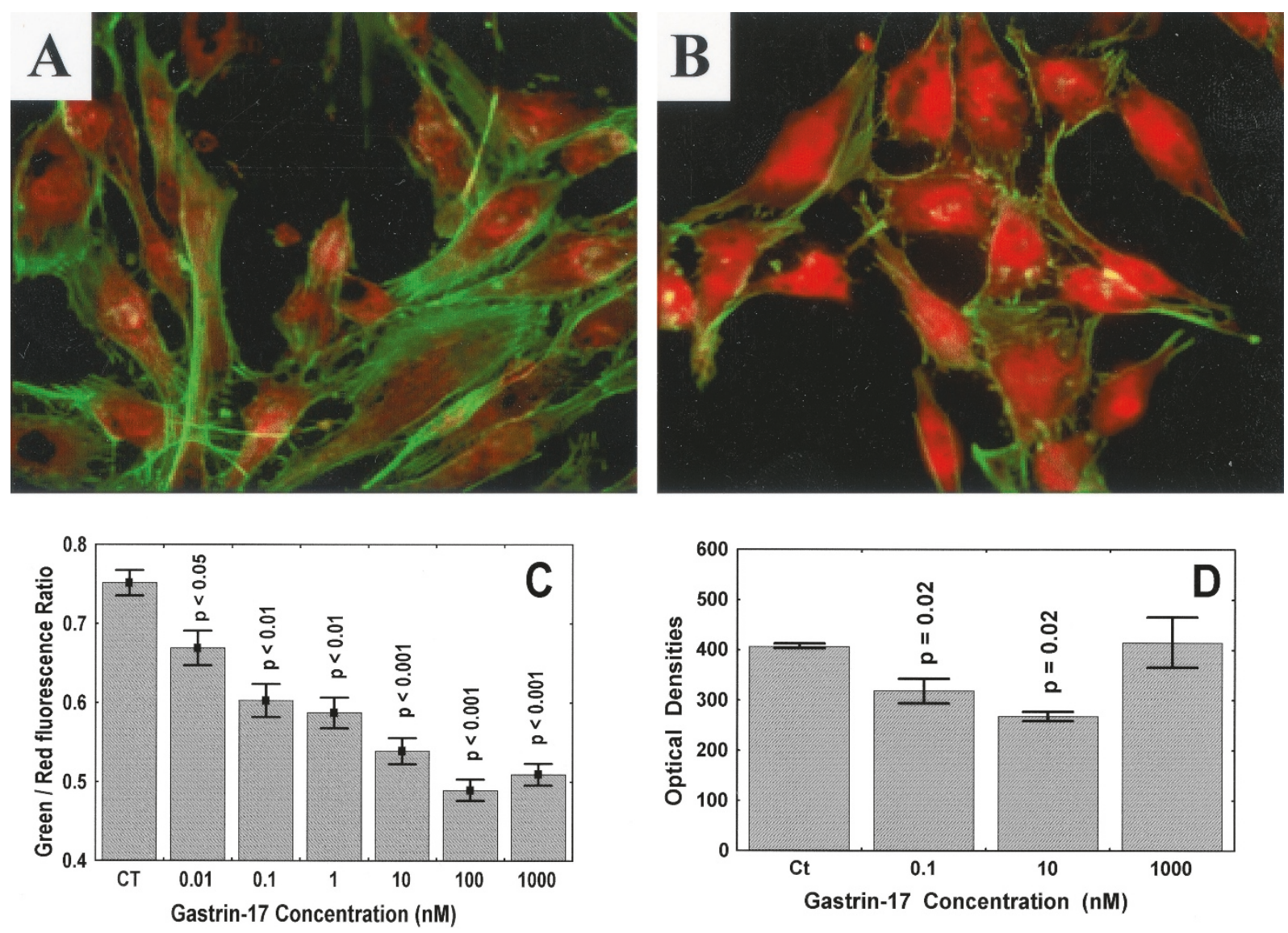

\section{Figure 3.}

A and B, Appearance of fibrillary (green fluorescence) as opposed to globular (red fluorescence) actin in C6 tumor astrocytes cultured for 24 hours, with (B) and without (A) $10^{-8} \mathrm{M}$ gastrin. C, Characterization of the influence of gastrin assayed at six concentrations ( $C T=$ control) with respect to the relative amounts of fibrillary (green fluorescence in A and B) to globular (red fluorescence in A and C) actin quantitatively determined by means of computer-assisted fluorescence microscopy. The data are reported as means \pm their standard errors. Statistical analyses were performed by means of the Dunn procedure. D, Influence of gastrin on the expression of the RhoA protein (quantitatively determined by means of Western blotting analyses) compared with control (CT). C6 cells were incubated for 24 hours in the presence (or the absence in control) of the various gastrin concentrations before proteins were extracted for Western blotting analysis. The data are presented as mean \pm SEM values. Four independent experiments were carried out.

second experiment performed 6 months later (not shown).

Although direct gastrin-induced modifications to glioma progression are strongly suggested by the data detailed in Figures 2, 3, and 4, it is nevertheless surprising that the in vitro gastrin-pretreatment of the C6 cells could alone be responsible for such significant increases in the rats' survival (Fig. 4A). Indeed, because the $\mathrm{C} 6$ glioma model is allogenic (Parsa et al, 2000), some gastrin-induced immune-mediated effects must also be considered in addition to the suspected gastrin-induced effects at migration level. We therefore conducted a new set of experiments in which we investigated whether gastrin was associated with any immunomodulatory effects. For this purpose we implanted C6 tumor cells by means of stereotactic procedures and surgically removed the glioma bulk some weeks later, as detailed in the "Materials and Methods." The data illustrated in Figure 4B show that gastrin delivery carried out on the same day as surgery (open circles) seems to have triggered a weak, but nevertheless statistically significant, benefit in terms of survival in the case of approximately 10 of the 18 rats included in this experimental group. This effect must to be compared with the one observed in the group of 18 rats that underwent surgery without subsequent gastrin delivery (filled circles). This benefit occurred mainly during the 2 weeks after the end of the gastrin delivery, that is, from Day 7 to Day 21 after surgery. No benefit from any treatment (ie, surgery alone or surgery and gastrin release) was observed in the case of the $9 \mathrm{~L}$ gliosarcoma (not shown). All of the animals grafted with the $9 \mathrm{~L}$ gliosarcoma died between 2 and 7 days after they had begun to lose weight (not shown).

Two long-term survival rats (grafted with the C6 glioma) that underwent surgery but no subsequent gastrin delivery (asterisks; Fig. 4B) and six in the surgery-plus-gastrin-delivery group (open circles; Fig. 4B) were killed 60 days after surgery for the histopathologic examination of their brains. In the same way, brains of the five $9 \mathrm{~L}$ gliosarcoma-bearing rats that had undergone surgery alone and brains of the five rats that had undergone both surgery and gastrin release were also submitted to histopathologic examination (Fig. 5). 

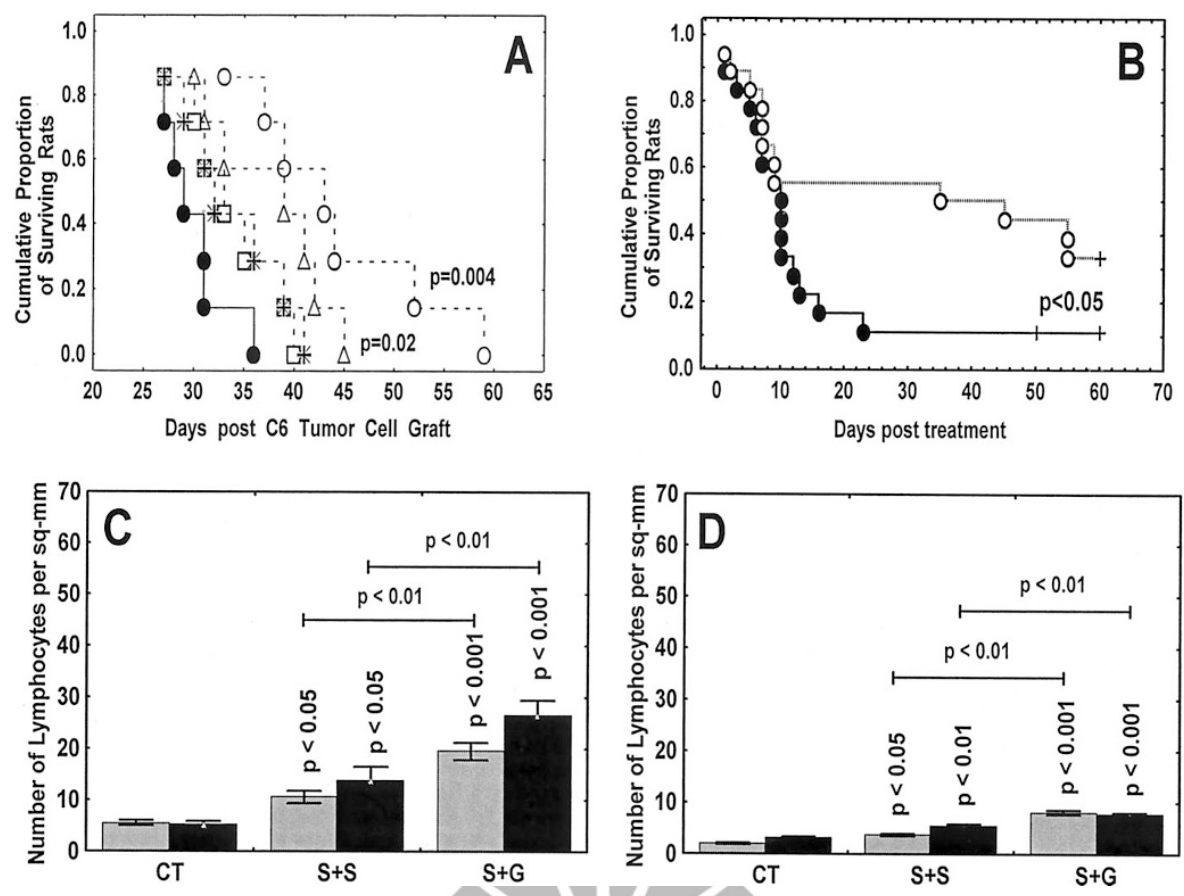

Figure 4.

$\mathrm{A}$ and B, Survival curves for the $\mathrm{C} 6$ glioma-bearing rats. A, the $\mathrm{C} 6$ cells were cultured for 24 hours in the presence of $10^{-12} \mathrm{M}$ (asterisks), $10^{-10} \mathrm{M}$ (open triangles), $10^{-8} \mathrm{M}$ (open circles), and $10^{-6} \mathrm{M}$ (open squares) gastrin or its absence (control; filled circles), before being stereotactically implanted (100,000 C6 cells/50 $\mu$ l/rat) into the rat brains. B, Fifty rats each had 100,000 C6 cells stereotactically grafted into their brains. Weekly monitoring of the weight of each rat showed that 36 of 50 C6 glioma-implanted rats began to lose weight between 19 and 24 days after C6 tumor cell implantation. Nuclear magnetic resonance (NMR) imaging was performed on each of the 36 rats and evidenced huge tumors in each of their brains. Thanks to pinpointing by NMR imaging, each rat underwent surgery to remove the bulk of its C6 glioma. Surgery was carried out when a rat had lost $10 \%$ of its weight relative to its weight the previous week. Micropumps were installed subcutaneously on the backs of the rats during surgery, immediately after the removal of C6 glioma bulk. The pumps delivered either saline (filled circles in B; 0.25 $\mu \mathrm{l}$ per hour) or $10^{-8} \mathrm{M}$ gastrin (open circles in B; $0.25 \mu \mathrm{l}$ per hour) for 14 days. Each group contained 18 rats. Two rats in Group A (without gastrin) and six rats in Group B (with gastrin) were long-term survivors; they were killed 60 days after surgery for the histopathologic examination of their brains (Fig. 5). C and D, Determination of the number of lymphocytes per square millimeter of brain tissue in three groups of rats implanted with C6 gliomas (C) or 9L gliosarcomas (D). Ten histologic fields were analyzed at magnification $\times 200$ for two tissue types for each brain analyzed, ie, the brain parenchyma surrounding the tumor (shaded bars) versus the tumor itself (black bars). The first group (CT group in $\mathrm{C}$ and D) included five rats implanted with $\mathrm{C6}$ gliomas (C) or $9 \mathrm{~L}$ gliosarcomas (D) and killed 14 days after the stereotactic implantation of $100,000 \mathrm{C} 6$ or 40,000 - $\mathrm{L}$ tumor cells. The second group ( $S+S=$ surgery + saline) included the two long-term $\mathrm{C} 6$ survivors and five $9 \mathrm{~L}$ tumors, whereas the third group $(S+G=$ for surgery + gastrin) included the six long-term $C 6$ survivors and five $9 L$ tumors.

We used three groups of rats implanted with either C6 gliomas (Fig. 4C) or 9L gliosarcomas (Fig. 4D) to quantify the number of lymphocytes per square millimeter of brain tissue. For each brain analyzed, 10 histologic fields were analyzed at magnification $\times 200$ for two tissue types: first, the brain parenchyma surrounding the $\mathrm{C} 6$ glioma or the $9 \mathrm{~L}$ gliosarcoma (shaded bars); and then the $\mathrm{C} 6$ glioma or the $9 \mathrm{~L}$ gliosarcoma itself (black bars; Fig. 4, C and D). The first group included five rats implanted with $\mathrm{C} 6$ gliomas or $9 \mathrm{~L}$ gliosarcomas and killed 14 days after the stereotactic implantation of $100,000 \mathrm{C} 6$ or 40,000 9L tumor cells. The second group $(S+S=$ surgery + saline) included the two long-term $C 6$ survivors from Group $A$ and five $9 L$ tumors. The third group $(S+G=$ surgery + gastrin) included the six long-term survivors from Group $B$ and five $9 \mathrm{~L}$ tumors. The data detailed in Figure $4, C$ and $D$ show that lymphocytes were present in the brain parenchyma surrounding the $\mathrm{C} 6$ gliomas, in the gliomas themselves (Fig. 5), in the brain parenchyma surrounding the 9L gliosarcomas, and in the 9L gliosarcomas themselves. This was the case even with the rats that had not undergone treatment. Surgery without gastrin delivery significantly increased the lymphocyte invasion in both the $\mathrm{C} 6$ gliomas and the $9 \mathrm{~L}$ gliosarcomas. These features occurred both in the brain parenchyma surrounding the tumors and in the tumors themselves. Surgery and then gastrin delivery markedly increased the lymphocyte invasion as compared with what happened in the other two groups, the $\mathrm{C} 6$ gliomas and the $9 \mathrm{~L}$ gliosarcomas. The effects were more pronounced in the allogenic $\mathrm{C} 6$ model than in the $9 \mathrm{~L}$ syngeneic model (Fig. 4, C and D).

It should be emphasized that lymphocyte counting was not performed at the same time after the delivery of gastrin to the $\mathrm{C} 6$ as in the $9 \mathrm{~L}$ tumors. We performed this counting when the tumor-bearing animals had begun to die; the $9 \mathrm{~L}$ tumor-bearing rats (treated by gastrin with surgery or left untreated) died sooner than the $\mathrm{C} 6$ tumor-bearing ones.

The low level of success attained by surgery alone in curing the animals bearing the C6 gliomas (2 of 18; Fig. $4 \mathrm{~B}$ ), or the $9 \mathrm{~L}$ gliosarcomas ( 0 of 5 ; not shown), seems to relate to the highly invasive nature of these $\mathrm{C} 6$ and $9 \mathrm{~L}$ models (Fig. 5). Figure 5A illustrates the highly invasive nature of the $\mathrm{C} 6$ glioma with respect to rat brains. Figure $5 \mathrm{~B}$ illustrates the high proliferative activity of this $\mathrm{C} 6$ glioma. Figure $5 \mathrm{C}$ illustrates the morphology of a rat 

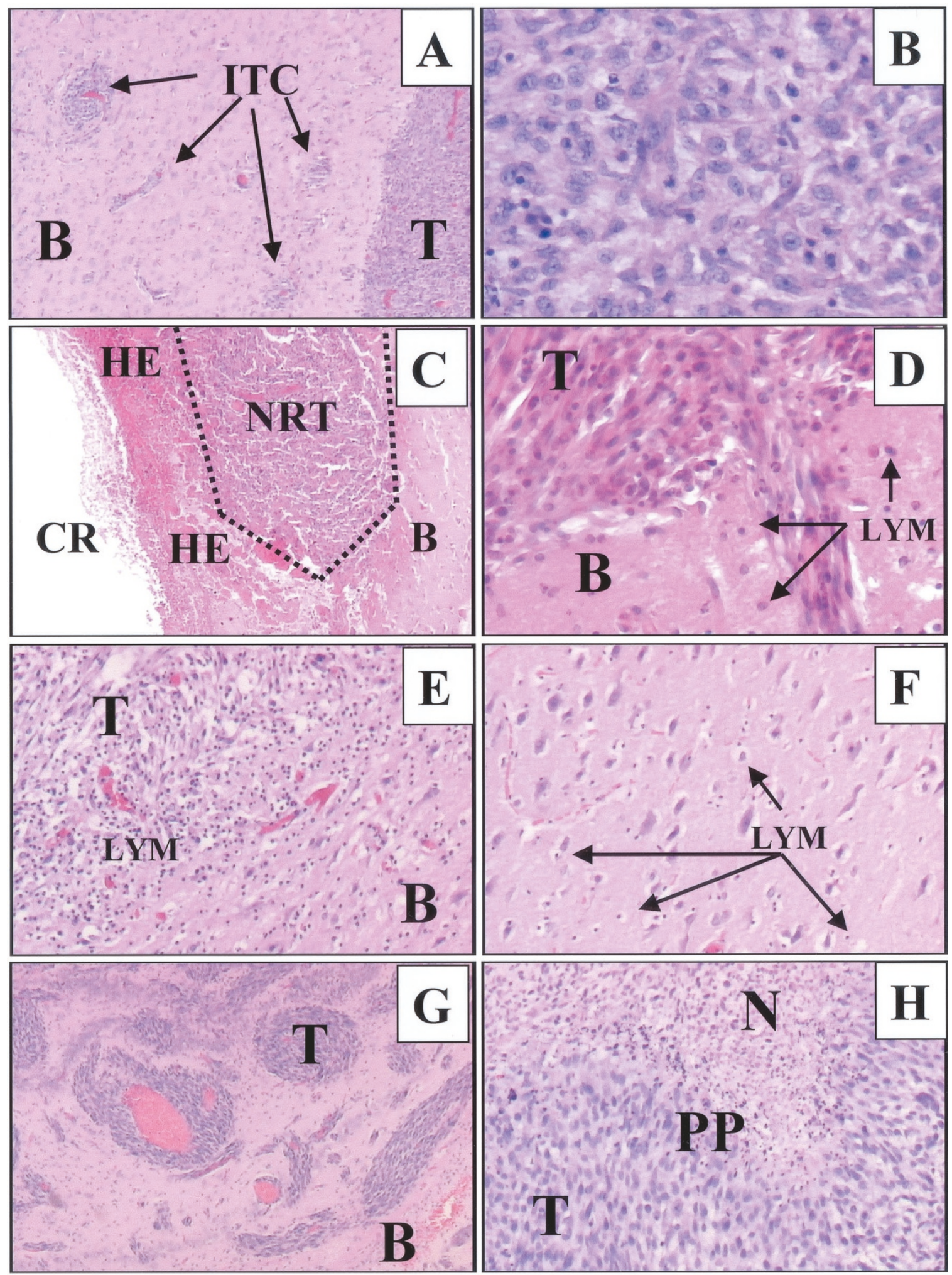

Figure 5.

Histopathologic examinations of the brains of the $\mathrm{C} 6$ glioma- and $9 \mathrm{~L}$ gliosarcoma-bearing rats submitted to various experimental conditions. A, (original magnification, $\times 40$ ) and B, (original magnification, $\times 400$ ), The histologic appearance of a C6 glioma implanted into the brain of a rat not otherwise treated. B, presence of mitoses and lymphocytes. C, (original magnification, $\times 40$ ) and D, (original magnification, $\times 400$ ), The histologic appearance of the brain of a rat that had undergone surgery, with saline then delivered to the resection cavity for 1 week by means of the micropump. The rat died 12 days after surgery. E, (original magnification, $\times 100$ ) and $\mathrm{F}$, (original magnification, $\times 100$ ), The delivery of gastrin into the cavity of resection in the brain of a C6 glioma-bearing rat resulted in a marked lymphocyte invasion of the surgical resection site and in the surrounding brain parenchyma. G. The $9 \mathrm{~L}$ gliosarcoma exhibits dramatic invasive features. H, The $9 \mathrm{~L}$ gliosarcoma exhibits pseudopalisading processes surrounding necrotic areas adjacent to the tumor bulk. $B$, brain; $C R$, cavity of resection; $H E$, hemorrhagic area; ITC, infiltrating tumor cell; $L Y M$, lymphocytes; $N$, necrotic area; $N R T$, nonresected tumor; PP, pseudopalisading processes; $T$, tumor. 
brain after surgery; saline was delivered to the resection cavity for 1 week by means of a micropump, and the rat died 12 days after surgery. Hemorrhagic areas and wound healing processes were present, as were unresected parts of the C6 glioma (Fig. 5C). Lymphocyte invasion was weak in this brain, the rat underwent surgery and saline (but not gastrin) delivery into the tumor resection cavity (Fig. 5C). Such lymphocyte invasion was also marked both in the tumor itself and in the brain parenchyma surrounding the tumor (Fig. 5D). Lymphocyte invasion was also weak in a C6 glioma implanted into the brain of a rat that did not undergo surgery (Fig. 5B). However, the presence of even a low percentage of lymphocytes emphasized the allogenic nature of the $\mathrm{C} 6$ gliomas grafted into the Wistar rats. The delivery of gastrin into the tumor resection cavity of a rat that underwent both surgery and gastrin delivery resulted in a marked lymphocyte invasion of the tissue surrounding the surgical resection cavity and, consequently, the gastrin delivery site (Fig. 5E). This invasion also affected the brain at a distance from the resection site (Fig. 5F).

The 9L gliosarcoma model exhibited very aggressive biologic characteristics (Fig. 5G), with some histopathologic features representative of high-grade gliomas including, for example, pseudopalisading processes surrounding large areas of necrosis in the tumor bulk (Fig. 5H).

\section{Discussion}

The present study deals with the characterization of gastrin-induced effects on glioma progression. Normal astrocytes possess significant amounts of $\mathrm{CCK}_{\mathrm{B}}$ receptors (Hosli and Hosli, 1994), and this type of gastrin receptor might be a major primary target for CCK/gastrin peptides in the CNS (Muller et al, 1997). Tumor astrocytes deriving from low-grade astrocytic tumors (ie, WHO Grade II astrocytomas) also frequently exhibit significant amounts of $\mathrm{CCK}_{\mathrm{B}}$ receptors (Reubi et al, 1997). In contrast, high-grade astrocytic tumors (WHO Grade IV glioblastomas) express no $\mathrm{CCK}_{\mathrm{B}}$ receptors (Reubi et al, 1997). The present data suggest that $\mathrm{CCK}_{\mathrm{B}}$ receptors could be replaced by $\mathrm{CCK}_{\mathrm{C}}$ receptors in high-grade astrocytic tumors (Fig. 1). The present study shows that whereas U373 tumor astrocytes do not exhibit the mRNAs of $\mathrm{CCK}_{\mathrm{A}}$ or $\mathrm{CCK}_{\mathrm{B}}$ receptors, they do exhibit the mRNAs of $\mathrm{CCK}_{\mathrm{C}}$ receptors (Fig. 1). Although $\mathrm{C} 6$ cells do not exhibit the mRNAs with respect to $\mathrm{CCK}_{\mathrm{A}}$ receptors, mRNAs of $\mathrm{CCK}_{\mathrm{B}}$ receptors are present (Fig. 1). The reverse feature was observed with respect to the $9 \mathrm{~L}$ tumor cells. The C6, 9L, and U373 tumor cells produce weak, but nevertheless significant, amounts of gastrin in their culture media (Fig. 1).

We have already shown that gastrin triggers significant effects with respect to both the cell proliferation (Camby et al, 1996) and the migration (De Hauwer et al, 1998) features of tumor astrocytes. Using a subtractive hybridization PCR technique we cloned genes differentially over-expressed in U373 human astrocytoma cells treated with gastrin or left untreated (Ku- charczak et al, 2001). We found approximately 70 genes over-expressed by gastrin, among which we identified the tenascin-C, the S100A6 (calcyclin), and the MLCK genes (Kucharczak et al, 2001), all of which are directly involved in cell migration features (Cramer and Mitchison, 1993; Lauffenburger and Horwitz, 1996). We also showed by means of a reporter gene system that the promoters of calcyclin and tenascin- $C$ were up-regulated after gastrin treatment (Kucharczak et al, 2001). We also identified calcyclin as a prognostic marker in human astrocytic tumors (Camby et al, 1999, 2000).

Unlike U373 cells, C6 cells exhibit $\mathrm{CCK}_{\mathrm{B}}$ gastrin receptors. In the present study, we chose the $\mathrm{C} 6$ rat and the U373 glioma models because they exhibit distinct types of gastrin receptors. The data that we obtained in previous in vitro studies all clearly indicated that gastrin targets multiple genes in tumor astrocytes, with marked consequences at proliferation and migration levels. However, no study to date has reported the effects mediated in vivo by gastrin on glioma progression. Even when in these earlier studies we identified some genes that seemed to be more or less specific targets for gastrin, we offered no explanation regarding to how gastrin is able to modulate cell proliferation in tumor astrocytes, nor how it modulates tumor astrocyte migration.

In the present study, we demonstrated both in vitro and in vivo that gastrin significantly modifies actin polymerization/depolymerization dynamics and, consequently, the organization of the actin cytoskeleton, and this could at least partly explain the gastrininduced modifications to tumor astrocyte migration. These gastrin-induced modifications observed in the organization of the actin cytoskeleton are mediated, at least in part, by a gastrin-induced decrease in RhoA expression. RhoA, is known to be one of the most potent regulators controlling the organization of the actin cytoskeleton (Chrzanowska-Wodnicka and Burridge, 1996; Hall, 1998; Klemke et al, 1998). Taniguchi et al (1996) showed that gastrin targets RhoA, which, in turn, modifies the organization of the actin cytoskeleton. These authors also showed that CCK and gastrin promote the growth of fibroblastic NIH3T3 cells into which the CCK-B/gastrin receptor has been introduced, and that these peptides regulate stress fiber formation in an Rho/p21-dependent manner. They thus argue that the signals from CCK-B/gastrin receptors might affect cell growth, cell motility, and cell adhesion by regulating the actin cytoskeleton, a point that has recently been corroborated by Danen et al (2000), who show that RhoA is able to interact with several cyclin/cdk complexes in driving cells through the G1 phase of the cell cycle.

The gastrin-induced activation of various biologic processes is mediated by mitogen-activated protein kinase (MAPK)-induced c-fos gene transcription via protein kinase C (PKC)-dependent and C (PKC)independent pathways (Stepan et al, 1999a, 1999b). Among other things, gastrin acts on the Sis-inducible element (SIE), the serum response element (SRE), and the $\mathrm{Ca}^{2+} / \mathrm{cAMP}$ response element (CRE), all of which 
regulate the c-fos promoter (Stepan et al, 1999a, 1999b). Although activation of the SRE involves the small GTP-binding protein RhoA, gastrin targets the c-fos promoter CarG sequence via the RhoAdependent pathways that play major roles in cell motility (Goodson et al, 1997; Maekawa et al, 1999). As mentioned above, gastrin can activate the PKCdependent pathway that plays a dramatic role in tumor astrocyte migration (Janik et al, 1992; Zhang et al, 1997).

The data detailed in Figure 4, C and D show that lymphocytes are present both in the brain parenchyma surrounding C6 gliomas and in the gliomas themselves. This also applies, but to a lesser extent, to $9 \mathrm{~L}$ gliosarcomas. This phenomenon could relate to the allogenic nature of the $\mathrm{C} 6$ glioma model as opposed to the syngeneic nature of the $9 \mathrm{~L}$ gliosarcoma model (Parsa et al, 2000). In both models (Fig. 4, C and D), surgery without gastrin delivery significantly increased lymphocyte invasion compared with the control group. This feature also occurred both in the brain parenchyma surrounding the gliomas and in the gliomas themselves, and could relate to the endogenous release of gastrin and/or cholescytokinin by rats stressed by anesthesia and surgery (Bhatnagar et al, 2000; Koks et al, 2000; Tsutsumi et al, 1999). In stressed rats, gastrin/CCK peptides are probably secreted from neurons in the lateral parabrachial, the periaqueductal gray matter, and/or the dorsal raphe nuclei (Bhatnagar et al, 2000). Surgery and gastrin delivery markedly increased lymphocyte invasion compared with the other groups (Fig. 4, C and D). The phenotypical profiles could well be different in the case of the lymphocytes present in and around the C6 gliomas and the $9 \mathrm{~L}$ gliosarcomas from the rats that underwent no further treatment, in the case of the lymphocytes in the rats that underwent surgery alone, and in the case of the lymphocytes in the rats that underwent surgery followed by gastrin delivery. We are now characterizing these immunologic profiles. In addition, whether these lymphocytes are activated against $\mathrm{C} 6$ and $9 \mathrm{~L}$ tumor cells remains to be seen. It also remains to be seen whether gastrin induces specific immunomodulatory effects on the lymphocytes that it recruits, and particularly in addition to its chemotactic influence evidenced both here (Figs. 4 and 5) and earlier by de la Fuente et al (2000).

In conclusion, our data show clearly that in vitro gastrin is able to significantly modulate the invasion and motility features of C6 and U373 cells. Gastrin significantly increased the survival periods of the C6 glioma-bearing rats, not only through modifications in the context of tumor astrocyte migration features, but possibly also through immunomodulatory influences including lymphocyte recruitment in the C6 gliomas.

\section{Materials and Methods}

\section{Cells and Compounds}

The C6 rat glioma, the $9 \mathrm{~L}$ rat gliosarcoma, and the U373 human glioma models were obtained from the
American Type Culture Collection (ATCC, Manassas, Virginia) and were maintained as monolayers. Also ordered from the ATCC were the human Jurkat (acute $T$ cell leukemia) cells that we used as a positive control for $\mathrm{CCK}_{\mathrm{B}}$ receptor determination, and the human LoVo colon cancer cells that we used as a positive control for $\mathrm{CCK}_{\mathrm{C}}$ receptor determination. Gastrin (pGlu-Gly-Pro-Trp-Leu-Glu-Glu-Glu-Glu-Glu-Ala-TyrGly-Trp-Met-Asp-Phe- $\mathrm{NH}_{2}$ ) was purchased from Sigma (St. Louis, Missouri). The L-365,260 compound (3R-3-[N'-(3-methylphenyl)ureido]-1,3-dihydro-1methyl-5-phenyl-2H-1,4-benzodiazepine-2-one) was obtained from ML Laboratories PLC (London, United Kingdom).

\section{Analysis of $\mathrm{CCK}_{A}, \mathrm{CCK}_{B}, \mathrm{CCK}_{C}$, and Gastrin RNA Expression}

The U373, C6, and 9L tumor cells were grown to subconfluence in plastic Falcon dishes (Nunc-Gibco BRL, Life Technologies, Merelbeke, Belgium) and lysed by adding Tripure Isolation Reagent (Roche, Mannheim, Germany). Total RNA was prepared according to the manufacturer's recommendation. Before cDNA synthesis, the RNA was incubated with DNAsel $(1.71 \mathrm{lU} / \mu \mathrm{l})$ (Roche Diagnostics, Mannheim, Germany) for 15 minutes at $37^{\circ} \mathrm{C}$. The RNA was purified by phenol/chloroform extraction. One microgram of total RNA was used as a template for CDNA synthesis. Reverse transcription was performed for 50 minutes at $42^{\circ} \mathrm{C}$ in $\mathrm{RT}$ buffer $(250 \mathrm{~mm}$ Tris- $\mathrm{HCl}, \mathrm{pH}$ 8.3, $375 \mathrm{~mm} \mathrm{KCl}, 15 \mathrm{~mm} \mathrm{MgCl} 2,10 \mathrm{~mm}$ DTT; Gibco), oligodT (12-18) primers (25 ng/ $\mu$; Gibco), $500 \mathrm{~nm}$ dNTP, 8 IU RNAsin Ribonuclease Inhibitor (Promega, Leiden, The Netherlands), and 200 IU Superscript BNAse $\mathrm{H}$ Reverse Transcriptase (Gibco). The reaction was terminated by incubation for 15 minutes at $70^{\circ} \mathrm{C}$.

\section{Integrity of the CDNA Confirmed by $\beta$-actin Specific PCR Analysis}

The primers for the $\mathrm{CCK}_{\mathrm{A}}$ and $\mathrm{CCK}_{\mathrm{B}}$ receptors and gastrin-17 were designed using the HYBsimulator software (Advanced Gene Computing Technologies, Irvine, California) (Hyndman et al, 1996), and were purchased from BioSource Europe S.A. (Nivelles, Belgium). The primers used for $\mathrm{C} 6$ and $9 \mathrm{~L}$ rat tumor cells were CCK $_{A}: 5^{\prime}$-CTTCATGAACAAACGCTाTCG-3' sense and 5'-CCATAATTCTACAGGAGCAGAA-3' antisense; CCK $_{\mathrm{B}}$ : 5'-ACAGATAGGAGTCTCATAGGA-3' sense and 5'-ACCTACCTCAAGAAGTCCA-3' antisense; and gastrin-17: 5'-GTGCATGCTAGTCTTAGTGC-3' sense and 5'-AGCATTGCTAGTTATACTGGTC-3' antisense.

\section{PCR Products Analyzed by Electrophoresis on 1\% Agarose Gels}

Because the presence of a third CCK receptor, the 72-kd CCK ${ }_{\mathrm{C}}$ receptor (Baldwin, 1994), has been reported in human tumors, we assayed the presence of $\mathrm{CCK}_{\mathrm{A}}, \mathrm{CCK}_{\mathrm{B}}$, and $\mathrm{CCK}_{\mathrm{C}}$ mRNAs in the U373 human glioma model. RNA extraction, DNAse treatment, and 
Reverse Transcription were performed as described above for the $\mathrm{C} 6$ and $9 \mathrm{~L}$ rat tumor cells.

The primers for the $\mathrm{CCK}_{\mathrm{A}}, \mathrm{CCK}_{\mathrm{B}}$, and $\mathrm{CCK}_{\mathrm{C}}$ receptors and gastrin-17 were designed using the HYBsimulator software and were purchased from BioSource Europe S.A. (Nivelles, Belgium). The primers used were: CCK $_{A}$ : 5'-CTGCTCAGCTGCTGGGAAAC-3' sense and 5'-CGGGACTGTAAGGGTTTGCAAAT-3' antisense; CCK $_{\mathrm{B}}$ : 5'-CCCATAGAAACATGACACTG -3' sense and 5'-GAGATTAGGCCTGATGGTATT-3' antisense; CCK ${ }_{C}$ : 5'-TGGATAGTATTTAGCGAGTCTG-3' sense and 5'-CTTCTCGTTACTCTGATAAATCTAG-3' antisense; and gastrin-17: 5'-CGAGATGCAGCGACTATG-3' sense and 5'-GTTCTAGGATTGTTAGTTCTCATC-3' antisense.

\section{Quantitative ELISA Determination for Gastrin Production in Tumor Cells}

The level of gastrin- 17 secreted by C6, 9L, and U373 tumor cells in their culture media was evaluated by means of a 96-well ELISA assay (Biohit Plc, Helsinki, Finland) following the manufacturer's instructions. Briefly, this assay is based on a sandwich enzyme immunoassay using horseradish peroxidase conjugated with a biotin/avidin amplification system. This immunoassay is specific for gastrin-17 and no crossreactivity is observed with cholecystokinin, gastrin-34, or minigastrin.

\section{Quantitative Western Blotting Analyses}

Cytosol extracts from the C6 cells were prepared as described by Andrews and Faller (1991). Protein extracts containing $30 \mu \mathrm{g}$ (evaluated by the BCA protein assay; Pierce, Polylabo, Antwerp, Belgium) were loaded into each lane of a polyacrylamide gel (12\%) under denaturing and reductive conditions. After electrophoresis, the proteins were transferred onto a Polyscreen PVDF membrane (NEN Life Science Products, Boston, Massachusetts) by tank blotting. RhoA proteins were further immunodetected by specific affinitypurified monoclonal mouse-mouse anti-RhoA $(1 / 1,000$; Neomarkers) antibodies in conjunction with goat anti-mouse immunoglobulin $\mathrm{G}$ conjugated with horseradish peroxidase $(0.2 \mu \mathrm{g} / \mathrm{ml}$; NEN Life Science Products). The levels of expression of the RhoA proteins were quantitatively determined by means of a gel scanner and a Bioprofil Image Analysis Software (Vilber Lourmat, Marne La Vallée, France), as detailed previously (Belot et al, 2001; Nagy et al, 2001; Steinfeld et al, 2000).

\section{Determination of In Vitro Cell Motility}

The C6, 9L, and U373 cell motility levels were characterized by means of a device described elsewhere (De Hauwer et al, 1998; Delbrouck et al, 2002; Nagy et al, 2001) that enables the trajectories of living cells maintained in culture to be quantified. The greatest linear distance migrated by each cell was calculated from these trajectories. This distance refers to the maximum relative distance from the point of origin (the
MRDO quantitative variable) (De Hauwer et al, 1998; Delbrouck et al, 2002; Nagy et al, 2001). The experiments were performed over 24 hours, and one image was recorded every 4 minutes. Because each experiment was repeated independently three times, a minimum of 844 and a maximum of 1,008 cells were analyzed in each experimental condition.

\section{Determination of In Vitro Cell Invasion}

The C6, 9L, and U373 tumor cell invasion was determined by means of the thick collagen gel assay described by Vakaet et al (1991). The number (expressed as a percentage) of cells that migrated into a collagen matrix were recorded. Two independent sets of experiments were performed. The C6, 9L, and U373 tumor cells were cultured for 24 hours in the presence of four distinct doses of gastrin before being plated. Control took the form of $\mathrm{C} 6$ tumor cells cultured for 24 hours in the absence of gastrin before being plated onto the collagen matrix.

\section{Quantitative Determination of Actin Amounts}

The influence of gastrin concentrations of between 0.01 and $1,000 \mathrm{~nm}$ on the organization of the actin cytoskeleton was investigated by means of fluorescent probes, as we detailed elsewhere (Delbrouck et al, 2002; Nagy et al, 2001). Although fluorescent phallacidin conjugated with BODIPY-FL fluorochrome (Molecular Probes, Eugene, Oregon) was chosen to label the fibrillar actin, Texas red conjugated DNAsel (Molecular Probes) was chosen to label the glomerular actin. The relative quantification of filamentous and glomerular actin ratios was carried out by means of computer-assisted fluorescent microscopy based on the EXPLORER software (SambaTechnologies, Grenoble, France), as detailed elsewhere (Delbrouck et al, 2002; Nagy et al, 2001).

\section{In Vivo Survival Analyses}

c6 Tumor Cells Preincubated In Vitro with Gastrin. Five groups of 8 rats had 100,000 cells stereotactically implanted into their right frontoparietal lobes. The first group received $\mathrm{C} 6$ cells cultured in standard medium. The second, third, fourth, and fifth groups received $\mathrm{C} 6$ cells incubated before stereotactical implantation for 24 hours in media containing $10^{-12}, 10^{-10}, 10^{-8}$ and $10^{-6} \mathrm{M}$ gastrin, respectively. The animals' survivals were recorded. This experiment was repeated 6 months later.

C6 and 9L Tumor Cells Stereotactically Implanted into Rat Brains and then Treated with Gastrin. Fifty rats had 100,000 C6 cells stereotactically grafted into their brains exactly as detailed above for the implantation of the gastrin-pretreated $\mathrm{C} 6$ cells. Weekly monitoring of the weight of each rat showed that 36 of 50 C6 glioma-implanted rats began to lose weight 19 to 24 days after $\mathrm{C} 6$ tumor cell implantation. NMR imaging performed on each of these 36 rats evidenced a huge brain tumor in each case. Thanks to the localization of the gliomas by NMR imaging, each of the rats under- 
went surgery to remove the bulk of its C6 glioma. Surgery was carried out on each rat when it had lost $10 \%$ of its weight, compared with its weight measured the previous week.

During surgery, a micropump (Alzet micro-osmotic pump, model 1002; Alza Corporation, Palo Alto, California) was installed subcutaneously on the back of each rat, immediately after the removal of the C6 glioma bulk. These pumps delivered either saline (Group A; $0.25 \mu \mathrm{l}$ per hour) or $10^{-8} \mathrm{M}$ gastrin (Group B; $0.25 \mu \mathrm{l}$ per hour) for 14 days. The $A$ and $B$ groups each contained 18 rats. Identical experimental procedures were carried out with the 9L model (see "Results"). All of the in vivo experiments described were performed with the authorization of the Animal Ethics Committee of the Faculty of Medicine of the Universite Libre de Bruxelles (Agreement no. 55/LA 1230342).

\section{Statistical Analyses}

Statistical comparisons between the control and the treated groups were first made by the Kruskal-Wallis test (a nonparametric one-way ANOVA). In cases where this test revealed significant differences, we investigated whether any of the treated groups differed from the control. For this purpose, we applied the Dunn Procedure (two-sided test) for multiple comparisons adapted to the special case of comparisons between treatment and control, that is, only $k-1 \mathrm{com}$ parisons were made among the $k$ groups tested by the Kruskal-Wallis test, instead of the possible $k(k-1) / 2$ comparisons considered in the general procedure (Rosner, 1995; Siegel and Castellan, 1988). Survival analysis was performed by using Kaplan-Meier curves and Gehan's generalized Wilcoxon têst. All statistical analyses were carried out using Statistica (Statsoft, Tulsa, Oklahoma).

\section{References}

Andrews NC and Faller DV (1991). A rapid micropreparation technique for extraction of DNA-binding proteins from limiting numbers of mammalian cells. Nucleic Acids Res 19:2499.

Baldwin GS (1994). Antiproliferative gastrin/cholecystokinin receptor antagonists target the $78-\mathrm{kDa}$ gastrin binding protein. Proc Natl Acad Sci USA 91:7593-7597.

Belot N, Rorive S, Doyen I, Lefranc F, Bruyneel E, Dedecker R, Micik S, Brotchi J, Decaestecker C, Salmon I, Kiss R, and Camby I (2001). The molecular characterization of cellsubstratum attachments in human glial tumors relates to prognostic features. Glia 36:375-390.

Bhatnagar S, Viau V, Chu A, Soriano L, Meijer OC, and Dallman MF (2000). A cholecystokinin-mediated pathway to the paraventricular thalamus is recruited in chronically stressed rats and regulates hypothalamic-pituitary-adrenal function. J Neurosci 20:5564-5573.

Burger PC and Scheithauer BW, editors (1994). Tumors of the central nervous system. Atlas of tumor pathology. Washington, DC: Armed Forces Institute of Pathology.

Camby I, Lefranc F, Titeca G, Neuci S, Fastrez M, Dedecken L, Schafer BW, Brotchi J, Heizmann CW, Pochet R, Salmon I, Kiss R, and Decaestecker C (2000). Differential expression of $\mathrm{S} 100$ calcium-binding proteins characterizes distinct clinical entities in both WHO grade II and III astrocytic tumors. Neuropathol Appl Neurol 26:76-90.

Camby I, Nagy N, Lopes MB, Schafer BW, Maurage CA, Ruchoux MM, Murmann P, Pochet R, Heizmann CW, Brotchi J, Salmon I, Kiss R, and Decaestecker C (1999). Supratentorial pilocytic astrocytomas, astrocytomas, anaplastic astrocytomas and glioblastomas are characterized by a differential expression of S100 proteins. Brain Pathol 9:825-843.

Camby I, Salmon I, Danguy A, Pasteels JL, Brotchi J, Martinez J, and Kiss R (1996). Influence of gastrin on human astrocytic tumor cell proliferation. J Natl Cancer Inst 88:594600.

Chintala SK and Rao JK (1996). Invasion of human glioma: Role of extracellular matrix proteins. Front Biosci 1:324-339.

Chrzanowska-Wodnicka M and Burridge K (1996). Rhostimulated contractility drives the formation of stress fibers and focal adhesions. J Cell Biol 133:1403-1415.

Cramer L and Mitchison TJ (1993). Moving and stationary actin filaments are involved in spreading of postmitotic PtK2 cells. J Cell Biol 122:833-843.

Danen EH, Sonneveld P, Sonnenberg A, and Yamada KM (2000). Dual stimulation of Ras/Mitogen-activated protein kinase and RhoA by cell adhesion to fibronectin supports growth factor-stimulated cell cycle progression. J Cell Biol 151:1413-1422.

De Hauwer C, Camby I, Darro F, Migeotte I, Decaestecker C, Verbeek C, Danguy A, Pasteels JL, Brotchi J, Salmon I, Van Ham P, and Kiss R (1998). Gastrin inhibits motility, decreases cell death levels and increases proliferation in human glioblastoma cell lines. J Neurobiol 37:373-382.

de la Fuente M, Carrasco M, Del Rio M, and Hernanz A (1998). Modulation of murine lymphocyte functions by sulfated cholecystokinin octapeptide. Neuropeptides 32:225233.

de la Fuente M, Carrasco M, and Hernanz A (1997). Modulation of human neutrophil function in vitro by gastrin. $J$ Endocrinol 153:475-483.

de la Fuente M, Medina S, Del Rio M, Fernandez MD, and Hernanz A (2000). Effects of ageing on the modulation of macrophages functions by neuropeptides. Life Sci 67:21252135.

Delbrouck C, Doyen I, Belot N, Decaestecker C, Ghanooni R, de Lavareille A, Kaltner H, Choufani G, Danguy A, Vandenhoven G, Gabius HJ, Hassid S, and Kiss R (2002). Galectin-1 is overexpressed in nasal polyps under Budesonide and inhibits eosinophil migration. Lab Invest 82:147-158.

Giese A, Rief MD, Loo MA, and Berens ME (1994). Determinants of human astrocytoma migration. Cancer Res 54: 3897-3904.

Goodson HV, Valetti C, and Kreis TE (1997). Motors and membrane traffic. Cur Opin Cell Biol 9:18-28.

Hall A (1998). Rho GTPases and the actin cytoskeleton. Science 279:509-514.

Hosli E and Hosli L (1994). Binding of cholecystokinin, bombesin and muscarine to neurons and astrocytes in explant cultures of rat central nervous system: Autoradiographic and immunohistochemical studies. Neuroscience 61:63-72. 
Hyndman D, Cooper A, Pruzinsky S, Coad D, and Mitsuhashi M (1996). Software to determine optimal oligonucleotide sequences based on hybridization simulation data. Biotechniques 20:1090-1097.

Janik P, Szaniawska B, Miloszewska J, Pietruszewska E, and Kowalczyk D (1992). The role of protein kinase $C$ in migration of rat glioma cells from spheroid cultures. Cancer Lett 63:167-170.

Kleihues P and Cavenee WK, editors (2000). Pathology and genetics of tumours of the nervous system. International Agency for Research on Cancer (IARC) WHO Health Organization. Oxford: Oxford Press.

Klemke RL, Leng J, Molander R, Brooks PC, Vuori K, and Cheresh DA (1998). CAS/Crk coupling serves as "molecular switch" for induction of cell migration. J Cell Biol 140:961972.

Koks S, Mannisto PT, Bourin M, Shlik J, Vasar V, and Vasar E (2000). Cholecystokinin-induced anxiety in rats: Relevance of pre-experimental stress and seasonal variations. J Psychiatry Neurosci 25:33-42.

Kucharczak J, Pannequin J, Camby I, Decaestecker C, Kiss $\mathrm{R}$, and Martinez J (2001). Gastrin induces over-expression of genes involved in human U373 glioblastoma cell migration. Oncogene 20:7021-7028.

Lauffenburger DA and Horwitz AF (1996). Cell migration: A physically integrated molecular process. Cell 84:359-369.

Maekawa M, Ishizaki T, Boku S, Watannabe N, Fujita A, Iwamatsu A, Obinata T, Ohashi K, Mizuno K, and Narumiya S (1999). Signaling from Rho to the actin cytoskeleton through protein kinases ROCK and LIM-kinase. Science 285:895898.

Muller W, Heinemann U, and Berlin K (1997). Cholecystokinin activates CCKB-receptor-mediated Ca-signaling in hippocampal astrocytes. J Neurophysiol 78:1997-2001.

Nagy N, Brenner C, Markadieu N, Chaboteaux C, Camby I, Schäfer BW, Pochet R, Heizmann CW, Salmon I, Kiss R, and Decaestecker C (2001). S100A2, a putative tumor suppressor gene, regulates in vitro squamous cell carcinoma migration. Lab Invest 81:599-612.

Parsa AT, Chakrabarti I, Hurley PT, Chi JH, Hall JS, Kaiser MG, and Bruce JN (2000). Limitations of the C6/Wistar rat intracerebral glioma model: Implications for evaluating immunotherapy. Neurosurgery 47:993-1000.
Rehfeld JF and van Solinge WW (1994). The tumor biology of gastrin and cholecystokinin. Adv Cancer Res 63:295-347.

Reubi JC, Schaer JC, and Waser B (1997). Cholecystokinin (CCK)-A and CCK-B/gastrin receptors in human tumors. Cancer Res 57:1377-1386.

Rosner B (1995). Fundamentals of biostatistics. London: International Thomson Publishing.

Siegel S and Castellan NJ Jr (1988). Nonparametric statistics for the behavioral sciences, 2nd ed. Singapore: McGraw-Hill.

Steinfeld S, Maho A, Chaboteaux C, Daelemans P, Pochet R, Appelboom T, and Kiss R (2000). Prolactin upregulates cathepsin B and D expression in minor salivary glands of Sjögren's syndrome patients. Lab Invest 80:1711-1720.

Stepan VM, Dickinson CJ, Del Valle J, Matsushima M, and Todisco A (1999a). Cell type-specific requirement of the MAPK pathway for the growth factor action of gastrin. Am J Physiol 276:G1363-G1372.

Stepan VM, Tatewaki M, Matsushima M, Dickinson CJ, del Valle J, and Todisco A (1999b). Gastrin induces c-fos gene transcription via multiple signaling pathways. Am J Physiol 276:G417-G424.

Taniguchi T, Takaishi K, Murayama T, Ito M, Iwata N, Chihara K, Takai Y, and Matsui T (1996). Cholecystokinin-B/gastrin receptors mediate rapid formation of actin stress fibers. Oncogene 12:1357-1360.

Tsutsumi T, Akiyoshi J, Isogawa K, Kohno Y, Hikichi T, and Nagayama H (1999). Suppression of conditioned fear by administration of CCKB receptor antagonist PD135158. Neuropeptides 33:483-486.

Vakaet L Jr, Vleminckx K, Van Roy F, and Mareel M (1991). Numerical evaluation of the invasion of closely related cell lines into collagen type I gels. Invasion Metastasis 11:249260.

Zhang W, Law RE, Hinton DR, and Couldwell WT (1997). Inhibition of human malignant glioma cell motility and invasion in vitro by hypericin, a potent protein kinase $\mathrm{C}$ inhibitor. Cancer Lett 120:31-38. 